Рекомендована д. фрармац. наук, профр. Д. І. Дмитрієвським

УДК 615.071: 615.465.1

DOI 10.11603/2312-0967.2018.1.8612

\title{
ТЕХНОЛОГІЧНІ ПАРАМЕТРИ ВИРОБНИЦТВА ЛІПОСОМ 3 ОКСАЛІПЛАТИНОМ
}

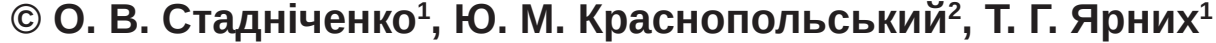

\author{
Національний фрармацевтичний університет ${ }^{1}$, Харків \\ Національний технічний університет «Харківський політехнічний інститут»², Харків \\ alstn31124@gmail.com
}

\begin{abstract}
Мета роботи. На основі експерименту запропонувати науково обґрунтовану технологію виробництва ліпосомальної орорми оксаліплатина. Провести аналіз проміжних продуктів, визначити контрольні точки.

Матеріали і методи. Для виготовлення ліпосом використовували яєчний фоосратидилхолін виробництва Lipoid (Німеччина). Дипальмітоілфосоратидилгліцерин, холестерин, розчинники використовували виробництва фрірми Sigma-Aldrich (США). Ліпідну плівку отримували на роторному випарнику Вuchi 210. Для гомогенізації використовували метод екструзії при високому тиску. Процес ліофілізації здійснювали на обладнанні Quarco (KHP). Результати й обговорення. Розроблено дослідно-промислову технологію отримання ліпосомальної фрорми оксаліплатину. Створення повноцінної технології вимагало вивчення колоїдних властивостей гетерогенної лікарської наносистеми, особливо на етапі регідратації, параметрів ліофрілізації, валідації методик контролю ступеня інкапсуляції оксаліплатину в ліпосоми, валідації кількісного визначення і визначення сторонніх домішок. Висновки. Запропоновано нову, оригінальну технологію отримання ліпосомальної фрорми оксаліплатину. Технологію апробовано на серіях препарату для проведення доклінічних досліджень.
\end{abstract}

Ключові слова: оксаліплатин; ліпосоми; фрармацевтична розробка; технологія; хроматографрія; ліофрілізація.

Вступ. У сучасній фрармацевтичній промисловості спостерігається зростання попиту на високотехнологічні ефективні лікарські засоби. Можна говорити про створення нової галузі фрармації, яка вивчає препарати, розміри яких знаходяться в нанодіапазоні [1]. Зростання інтересу до наноструктурованих препаратів, зокрема ліпосом, зумовлений виходом на новий рівень терапії й потенційною можливістю корекції недоліків вже існуючих препаратів [2, 3].

За минулі 10 років з'явилися десятки нових, ефективних терапевтичних засобів [4, 5]. Прикладом таких препаратів можуть слугувати «Visudyne» - ліпосомальна фрорма вертепорфірину, «Doxil» - ліпосомальна фрорма доксорубіцину, «Marqibo» - ліпосомальна форма вінкристину, «Onivyde» - ліпосомальна фрорма іринотекану, «AmBisome» - ліпосомальна фрорма амсротерецину В.

Особливо можна виділити ліпосоми як носій протипухлинних препаратів. Перспектива цих лікарських засобів зумовлюється можливістю зниження токсичності цитостатичних препаратів - основної перешкоди для повного розкриття їх терапевтичних можливостей. Це здійснюється не тільки за рахунок пасивного накопичення ліпосом в онкологічно змінених тканинах за рахунок EPR (Enhanced permeability and retention effect), але й за рахунок можливості застосування активних таргетних технологій і використання онкогенних маркерів на зовнішній поверхні ліпосом [6].
Оксаліплатин $є$ аналогом цисплатину, він схвалений до медичного застосування з 1996 р. Молекула оксаліплатину складається 3 центрального атома платини, оточеного двома лігандами - оксалатом і діаміноциклогексаном у транс-положенні відносно один одного. Терапевтична активність зумовлена взаємодією з ДНК і утворенням внутрішньоспіральних та міжспіральних зшивок. Ще одним фрактором, що зумовлює застосування оксаліплатину, є його активність щодо пухлин, резистентних до цисплатину і карбоплатину. Оксаліплатин ефективний як в одиночному застосуванні, так й у комбінації з іншими цитостатиками. Відзначається синергізм дії при одночасному застосуванні з іринотеканом [7].

Технології отримання ліпосомальної фрорми оксаліплатина були досліджені, в основному, на лабораторному рівні в обсягах до 10 мл без застосування обладнання промислового масштабу [8]. Ефективним способом отримання повноцінної та якісної технології отримання нанобіотехнологічного лікарського засобу є плавна, ступінчаста масштабізація технологічного процесу [9]. Можна стверджувати, що між лабораторною технологією і дослідно-промисловою апробацією необхідна стадія відпрацювання технології в лабораторії, але із застосуванням обладнання, що працює на загальних принципах із промисловим. У ході таких робіт збирається статистична та практична інорормація щодо перебігу різних режимів технологічного процесу. Така робота була проведена

ISSN 2312-0967. Pharmaceutical review. 2018. № 1 
Фармацевтична технологія, біофармація, гомеопатія Pharmaceutical technology, biopharmacy, homeopathy

і були отримані дані, необхідні для переходу на дослідно-промисловий рівень [10-13].

Мета рорботи - на основі проведеного експерименту запропонувати науково обґрунтовану технологію виробництва ліпосомальної форми оксаліплатину. Провести аналіз одержуваних проміжних продуктів, визначити контрольні точки.

Матеріали і методи. Для виготовлення ліпосом використовували яєчний фоссратидилхолін виробництва Lipoid (Німеччина). Дипальмітоілфосоратидилгліцерин, холестерин, розчинники використовували виробництва фрірми Sigma-Aldrich (США). Ліпідну плівку отримували на роторному випарнику Buchi 210 з вакуумним контролером при залишковому тиску 0,02 атм. Для гомогенізації використовували метод екструзії при високому тиску, яку проводили на установці Microfluidiser M-110P (Microfluidics, США). Ро3мір ліпосом визначали при $20^{\circ} \mathrm{C}$ на приладі Zetasizer Nano ZS (Malvern Instruments, Великобританія). Рівень інкапсуляції оксаліплатину в ліпосоми, концентрацію оксаліплатину і вміст сторонніх домішок контролювали методом високоефективної рідинної хроматографрії (BEPX) на хроматографрі Shimadzu LC-20 (Японія). Процес ліофрілізації здійснювали на обладнанні Quarco (KHP).

Результати й обговорення. Структура молекули оксаліплатину зумовлює особливості вибору допоміжних речовин у препараті. Так, наявність комплексоактивного атома платини виключає використання солей і буферних розчинів. При роботі з препаратом як розчинник використовується вода для ін'єкцій.

При дослідно-промисловому освоєнні технології виникає перелік невизначеностей, які потребують практичної апробації та вивчення. До таких питань можна віднести:

- перенесення моделі інкапсуляції з лабораторних досліджень, що реалізується за фрармацевтичної розробки, до пілотних або дослідно-промислових;

- підтвердження стабільності екструзійного етапу технології, оптимізація його параметрів під великі обсяги;

- вивчення колоїдних властивостей гетерогенної лікарської нано-системи, особливо на етапі регідратації;

- вивчення параметрів ліофілізації готового препарату при переході до більшого масштабу;

- валідація методик контролю ступеня інкапсуляції оксаліплатину в ліпосоми, валідація кількісного визначення і визначення сторонніх домішок.

Застосування ліпосомальної платорорми має незаперечну перевагу перед застосуванням інших, більш жорстких наночасток. Це можливість проведення стерильної фрільтрації й виключення необхідності реалізації технології в асептичних умовах, що позитивно позначається на освоєнні випуску і майбутньої вартості готового продукту.
На рисунку 1 представлено схематичне зображення технологічного процесу отримання ліпосомальної форми оксаліплатину.

Дослідження ліпідної мембрани показало, що оптимальним, з точки зору інкапсуляції оксаліплатину в ліпосоми, є наступний ліпідний склад: фоссратидилхолін / холестерин / дипальмітоілфосфратидилгліцерин. У ході фрармацевтичної розробки і оптимізації складу мембрани співвідношення фосоратидилхолін / холестерин / дипальмітоілфосоратидилгліцерин зі значення 70/20/10 було змінено до співвідношення 50:20:30. Було зменшено вміст нейтрального ліпіду фросфратадилхоліну і збільшено вміст зарядженого ліпіду дипальмітоілфоссратидилгліцерину, що поліпшило інкапсуляцію активної речовини. Такий склад забезпечує захоплення оксаліплатину за двома механізмами - ємнісне захоплення при гідратації ліпідної плівки розчином оксаліплатину і сорбційний механізм, зумовлений наявністю в мембрані зарядженого модифікатора - дипальмітоілфоссратидилгліцерину. Корекція складу мембрани не вплинула на розмір ліпосом.

На стадії 1 технології відбувається отримання ліпідної плівки шляхом розчинення ліпідів у суміші хлорофрорм - етанол, фрільтрація через фрільтр із розмірами пор 0,22 мкм і видалення розчинників на роторному випарнику під вакуумом. На стадії здійснюється контроль повноти розчинення ліпідів і перевірка їх концентрації в розчині.

На стадії 2 здійснюється гідратація отриманої ліпідної плівки розчином оксаліплатину в воді для ін'єкцій і отримання грубої емульсії. Концентрація оксаліплатину на цьому етапі становить 4 мг/мл, а ліпідів - 40 мг/мл. Підхід із використанням концентрованого в два рази, порівняно з готовим препаратом, розчину оксаліплатину і збільшений в два рази вміст ліпідів, покращує показники інкапсуляції. На цьому етапі здійснюється контроль концентрації оксаліплатину в розчині.

На стадії 3 здійснюється гомогенізація і стандартизація за розміром грубої емульсії ліпідів. При цьому

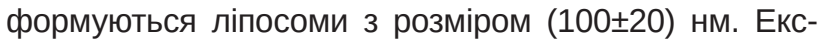
трузія проходить при режимі 1500 атм і обов'язковому охолодженні емульсії до $20{ }^{\circ} \mathrm{C}$. Було показано, що тиск 1500 атм не призводить до утворення великих агрегатів, не впливає на хімічну структуру оксаліплатине і не сприяє утворенню сторонніх домішок. На стадії здійснюється контроль розміру часток при кожному циклі екструзії, концентрації і сторонніх домішок в оксаліплатині, параметрів режиму екструзії.

На стадії 4 технологічного процесу до емульсії ліпосом додається розчин кріопротектора трегалози дигідрату. При цьому контролюється розмір часток, ступінь інкапсуляції оксаліплатину, а також кількість і концентрація розчину кріопротектора.

Стадія 5 перебігає в асептичних умовах. При цьому здійснюється стерилізуюча фрільтрація через поліесрірсульфоновий мембранний фрільтр із розміром

ISSN 2312-0967. Фармацевтичний часопис. 2018. № 1 
Фармацевтична технологія, біофармація, гомеопатія Pharmaceutical technology, biopharmacy, homeopathy

\begin{tabular}{|c|}
\hline СИРОВИНА I \\
НАПІВПРОДУКТИ \\
\hline
\end{tabular}

НАЗВА
ОПЕРАЦЇ̈

\section{АНАЛІТИЧНИЙ КОНТРОЛЬ}

\begin{tabular}{|c|}
\hline $\begin{array}{c}\text { Ліпіди, етанол, } \\
\text { хлороформ }\end{array}$ \\
\hline \hline $\begin{array}{c}\text { Плівка ліпідів, розчин } \\
\text { оксаліплатину }\end{array}$ \\
\hline \hline $\begin{array}{c}\text { Груба емульсія ліпідів } 3 \\
\text { оксаліплатином }\end{array}$ \\
\hline \hline
\end{tabular}

\begin{tabular}{c} 
СТАДІя 1 \\
Отримання ліпідної плівки \\
$\begin{array}{c}\text { СТАДІя } 2 \\
\text { Гідратація плівки розчином оксаліплатину. } \\
\text { Отримання грубої емульсії }\end{array}$ \\
$\begin{array}{c}\text { СТАДІя } 3 \\
\text { Гомогенізація грубої емульсії методом } \\
\text { екструзії }\end{array}$ \\
\hline
\end{tabular}

Концентрація ліпідів, повнота розчинення ліпідів

Концентрація оксаліплатину в розчині

Розмір часток, параметри екструзії, концентрація і сторонні домішки оксаліплатину

Емульсія ліпосом з оксаліплатином, розчин кріопротектора (трегалози дигідрат)

Емульсія ліпосом з оксаліплатином і кріопротектором, флакони, пробки

\begin{tabular}{|c|}
$\begin{array}{c}\text { СТАДІЯ } 4 \\
\text { Додавання розчину } \\
\text { кріопротектора }\end{array}$ \\
\hline СТАДІЯ 5
\end{tabular}

Стерилізуюча фільтрація в асептичних умовах. Розлив. Передзакупорення пробками

Емульсія ліпосом з оксаліплатином, розлита у флакони та передзакупорена

Ліофільно висушені ліпосоми у дозакупорених флаконах

Завальцьовані флакони

Вимиті, сухі флакони 3 ліофілізатом

\section{СТАДІЯ 6}

Ліофільна сушка. Дозакупорювання пробками

\section{СТАДІЯ 7}

Завальцювання флаконів алюмінієвими ковпачками

\section{СТАДІЯ 8}

Миття флаконів. Сушка флаконів стиснутим повітрям

СТАДІя 9
Маркування флаконів

Марковані флакони 3

ліофілізатом, вторинна упаковка

Марковані, упаковані флакони з ліофілізатом та інструкцією

\section{СТАДІЯ 10}

Вторинне пакування, вкладання інструкції

\section{СТАДІЯ 11}

Транспортування готової продукції на склад карантину
Розмір часток, ступінь інкапсуляції, кількість і концентрація розчину кріопротектора

Розмір часток, ступінь інкапсуляції, концентрація і сторонні домішки оксаліплатину

Режим ліофільної сушки, вміст залишкової води у ліофілізаті

Якість завальцювання

Якість миття, якість сушки

Якість маркування, відповідність назви препарату, дати випуску, серії

Якість вторинної упаковки, відповідність назви препарату, дати випуску, серії, інструкції

Повний контроль якості готової продукції

Рис. 1. Технологічна схема виробництва ліпосомального оксаліплатину.

пор 0,22 мкм. Одночасно відбувається розлив у фрлакони, які пройшли стерилізацію і депірогенізацію. Розлитий препарат закупорюється підготовленими пробками. На стадії, після розливу, контролюється розмір часток емульсії, ступінь інкапсуляції, вміст і сторонні домішки оксаліплатину. Так само здійснюється відбір проб на контроль стерильності.
Стадія 6 - ліофільна сушка і дозакупорювання відбувається у камері ліофілізаційної машини. Флакони в асептичних умовах поміщаються у попередньо охолоджену камеру машини. Камера герметизується, цикл ліофілізації займає 2040 хв або 34 години. В кінці процесу фрлакони дозакупорюються під вакуумом за допомогою полиць машини, що опускаються. На

ISSN 2312-0967. Pharmaceutical review. 2018. № 1 
Фармацевтична технологія, біофармація, гомеопатія Pharmaceutical technology, biopharmacy, homeopathy

стадії контролюється режим сушіння і вміст залишкової вологи у готовому продукті.

Стадія 7 передбачає завальцювання фрлаконів алюмінієвими ковпачками з паралельним контролем якості завальцювання. На стадії 8 фрлакони миють і сушать стисненим повітрям, контролюють якість мийки і якість сушіння. Стадія 9 і стадія 10 представляють собою маркування фрлаконів та вторинну упаковку із вкладанням інструкції із застосування. На стадії здійснюється контроль маркування, відповідності назви препарату, дати випуску, номера серії, якості упаковки і відповідність інструкції оригінал-макету. На стадії 11 здійснюється транспортування готової продукції на склад карантинного зберігання і проводиться повний контроль якості готової продукції.

Варто зазначити, що технологія вимагає одночасного використання при контролі двох ВЕРХ-систем, одна із яких налаштована на контроль ступеня інкапсуляції, а інша - на контроль кількісного вмісту оксаліплатину та його сторонніх домішок.
Технологію було розроблено на етапі фрармацевтичної розробки і апробовано в лабораторному і дослідно-промисловому масштабах. Проведено валідацію методик контролю якості. У ході подальших робіт, після проведення повної валідації технологічного процесу, планується оптимізація кількості контрольних точок для забезпечення стабільної якості продукції, що випускається. Запропоновану технологію використовували для отримання зразків препарату для доклінічних досліджень. За результатами доклінічних досліджень було отримано дозвіл на проведення першої фрази клінічних випробувань препарату.

Висновки. 1. Запропоновано нову, оригінальну технологію отримання ліпосомальної фрорми оксаліплатину. Вивчено технологічні режими та підібрано контрольні точки.

2. Технологія апробована на серіях препарату, що використовуються для проведення доклінічних досліджень. Підтверджено стабільність і відтворюваність технології.

\section{ТЕХНОЛОГИЧЕСКИЕ ПАРАМЕТРЫ ПРОИЗВОДСТВА ЛИПОСОМ С ОКСАЛИПЛАТИНОМ}

\section{А. В. Стадниченко ${ }^{1}$ Ю. М. Краснопольский ${ }^{2}$, Т. Г. Ярных ${ }^{1}$}

Национальный фрармацевтический университет ${ }^{1}$, Харьков Национальный технический университет «Харьковский политехнический институт»², Харьков alstn31124@gmail.com

Цель работы. На основе эксперимента предложить научно обоснованную технологию производства липосомальной формы оксалиплатина. Провести анализ промежуточных продуктов, определить контрольные точки.

Материалы и методы. Для изготовления липосом использовали яичный фросфатидилхолин производства Liроіd (Германия). Дипальмитоилфосфатидилглицерин, холестерин, растворители использовали производства фрирмы Sigma-Aldrich (США). Липидную пленку получали на роторном испарителе Buchi 210. Для гомогенизации использовали метод экструзии при высоком давлении. Процесс лиофилизации осуществляли на оборудовании Quarco (KHP).

Результаты и обсуждение. Была разработана опытно-промышленная технология получения липосомальной фрормы оксалиплатина. Создание полноценной технологии требовало изучения коллоидных свойств гетерогенной лекарственной наносистемы, особенно на этапе регидратации, параметров лиосилизации, валидации методик контроля степени инкапсуляции оксалиплатина в липосомы, валидации количественного определения и определения посторонних примесей.

Выводы. Предложена новая, оригинальная технология получения липосомальной фрормы оксалиплатина. Технология апробирована на сериях препарата, используемых для проведения доклинических исследований.

Ключевые слова: оксалиплатин; липосомы; фрармацевтическая разработка; технология; хроматография; лиосилизация.

\section{TECHNOLOGICAL PARAMETERS OF PRODUCTION OF LIPOSOMES WITH OXALIPLATIN}

\section{A. V. Stadnichenko', Y. M. Krasnopolsky², T. G. Yarnykh ${ }^{1}$}

National University of Pharmacy', Kharkiv

National Technical University "Kharkiv Polytechnic Institute"2, Kharkiv

alstn31124@gmail.com

The development of medicines of a nanoscale diapason opens a new trend in the modern pharmaceutical industry. Reducing the toxicity of known cytotoxic agents is one of the advantages of the liposomal biotechnology platform. The

ISSN 2312-0967. Фармацевтичний часопис. 2018. № 1 
aim of the work is to offer scientifically grounded technology of production of liposomal form of oxaliplatin based on the experiment. To analyze intermediate products, define control points.

Materials and Methods. Egg phosphatidylcholine produced by Lipoid, Germany was used to make liposomes. Dipalmitoylphosphatidylglycerin, cholesterol, solvents used by the company Sigma-Aldrich, USA. The lipid film was obtained on a rotary evaporator Buchi 210. For homogenization, an extrusion method at high pressure was used. The lyophilization process was carried out on Quarco equipment (PRC).

Results and Discussion. The experimental industrial technology of obtaining the liposomal form of oxaliplatin was developed. The development of a full-fledged technology requires the study of colloidal properties of a heterogeneous nanosystem, especially at the rehydration stage, lyophilization parameters, validation of control methods for the encapsulation of oxaliplatin into liposomes, validation of quantitative determination and determination of impurities.

Conclusions. A new, original technology and control points for obtaining liposomal form of oxaliplatin are proposed. The technology has been tested on batches of preparations, used for preclinical studies.

Key words: oxaliplatin; liposomes; pharmaceutical development; technology; chromatography; lyophilization.

\section{Список літератури}

1. Фостер Л. Нанотехнологии. Наука, инновации и возможности / Л. Фостер // Техносфрера. - 2006. - № 1. C. 2461.

2. Medical University of Vienna. Drug delivery using liposomes. ScienceDaily. - 2017. https://www.sciencedaily. com /releases/2017/10/171023180627.htm.

3. Liposomes and Nanotechnology in Drug Development: Focus On Pancreatic Cancer / A. Malik, J. Wei, A. Raheem [et al.] // Journal of Gastroenterology, Pancreatology \& Liver Disorders. - 2017. - Vol. 5. - P. 1-10.

4. Recent progress of liposomes in nanomedicine / $\mathrm{L}$. Hosta-Rigau, P. Schattling, B. Teo [et. al.] // Journal of Materials Chemistry B. - 2014. - Vol. 39. - P. 6686-6691.

5. Prospective clinical applications of nanosized drugs / Y. M. Krasnopolskii, V. Y. Balabanyan, D. L. Shobolov [et al.] // Russian J. of General Chemistry. - 2013. - Vol. 83, № 12. - P. 2524-2540.

6. Dai Z. Liposomal nanotechnology for cancer theranostics / Z. Dai, X. Yue // Curr. Med. Chem. - 2017. - Vol. 24. P 527-536.

7. Bartolomeo M. D. Capecitabine, oxaliplatin and irinotecan in combination, with bevacizumab (COI-B regimen) as firstline treatment of patients with advanced colorectal cancer. An Italian Trials of Medical Oncology phase II study / M. D. Bartolomeo, A. Ciarlo // European Journal of Cancer. - 2015. - Vol. 51. - P. 473-481.

\section{References}

1. Foster L. [Nanotechnology. Science, innovation and opportunities]. Tehnosfera 2006; 1: 2461. Russian.

2. Medical University of Vienna. Drug delivery using liposomes. ScienceDaily. - 2017. https://www.sciencedaily. com /releases/2017/10/171023180627.htm.

3. Malik A, Wei J, Raheem A. [Liposomes and nanotechnology in drug development: focus on pancreatic cancer]. Journal of Gastroenterology, Pancreatology \& Liver Disorders. 2017;5: 1-10.

4. Hosta-Rigau L, Schattling P, Teo B. [Recent progress of liposomes in nanomedicine]. Journal of Materials Chemistry 2014;39: 6686-91.

5. Krasnopolskii YM, Balabanyan VY, Shobolov DL. [Pro-
8. Стадниченко А. В. Некоторые аспекты получения липосомальной фрормы оксалиплатина / А. В. Стадниченко, Ю. М. Краснопольский, В.И.Швец // Тонкие химические технологии. - 2015. - Т. 10, № 1. - С. 60-65.

9. Краснопольский Ю. М. Исследование фракторов риска при производстве липосомальных лекарственных препаратов / Ю. М. Краснопольский, А. С. Григорьева, Н. Ф. Конахович // Фармакологія та лікарська токсикологія. -2011. - № 5 (24). - С. 174-175.

10. Stadnichenko A. V. The study of the lipid membrane charge effect when creating liposomes with oxaliplatin / A. V. Stadnichenko, Y. M. Krasnopolsky, T. G. Yarnykh // News of pharmacy. - 2016. - Vol. 4 (88). - P. 34-37.

11. Stadnichenko A. V. Standardization of Extrusion Parameters during Liposomal Oxaliplatin Creation / A. V. Stadnichenko, Y. M. Krasnopolsky, T. G. Yarnykh // Research J. Pharm. and Tech. - 2017. - Vol. 10 (3). P.785-788.

12. Стадниченко А. В. Изучение факторов, влияющих на стабильность липосом при регидратации / А. В. Стадниченко, Ю. М. Краснопольский, Т. Г. Ярных // Рецепт. - 2017. - №. 2 (20). - С. 146-153.

13. Стадниченко А. В. Исследование окисленности липидов при изготовлении липосом с цитостатиками / А.В.Стадниченко, Ю. М. Краснопольский, Т. Г. Ярных // Вестник фрармации. - 2017. - № 3. - С. 29-34.

spective clinical applications of nanosized drugs]. Russian J. of General Chemistry 2013;83(12): 2524-40. Russian.

6. Dai Z, Yue X. [Liposomal nanotechnology for cancer theranostics]. Curr. Med. Chem. 2017;24: 527-36.

7. Bartolomeo MD, Ciarlo A. [Capecitabine, oxaliplatin and irinotecan in combination, with bevacizumab (COI-B regimen) as first-line treatment of patients with advanced colorectal cancer. An Italian Trials of Medical Oncology phase II study]. European Journal of Cancer 2015;51: 47381.

8. Stadnichenko AV, Krasnopolskiy YuM, Shvets VI. [Some aspects of the preparation of liposomal form of oxaliplatin]. Tonkie khimicheskie tekhnologii 2015;10(1): 60-5. Russian.

ISSN 2312-0967. Pharmaceutical review. 2018. № 1 
Фармацевтична технологія, біофармація, гомеопатія Pharmaceutical technology, biopharmacy, homeopathy

9. Krasnopolskiy YuM, Grigoreva AS, Konahovich NF. [Investigation of risk factors in the manufacture of liposoma drugs]. Farmakolohiia ta likarska toksykolohiia. 2011;5(24): 174-5. Russian.

10. Stadnichenko AV, Krasnopolsky YM, Yarnykh TG. [The study of the lipid membrane charge effect when creating liposomes with oxaliplatin]. News of Pharmacy 2016;4(88): 34-7.

11. Stadnichenko AV, Krasnopolsky YM, Yarnykh TG. [Stan- dardization of extrusion parameters during liposomal oxaliplatin creation]. Research J. Pharm. and Tech. 2017;10(3): 785-8.

12. Stadnichenko AV, Krasnopolskiy YuM, Yarnykh TG. [Investigation of factors affecting the stability of liposomes during rehydration]. Retsept. 2017;2(20): 146-53. Russian. 13. Stadnichenko AV, Krasnopolskiy YuM, Yarnykh TG. [The study of lipid oxidation in the manufacture of liposomes with cytostatics]. Vestnik farmatsii 2017;3: 29-34. Russian.

Отримано 14.12.2017

ISSN 2312-0967. Фармацевтичний часопис. 2018. № 1 